\title{
Growth dynamic on a co-cultivation of two Chlorophyta microalgae exposed to copper
}

Dinâmica de crescimento no co-cultivo de duas microalgas Chlorophyta expostas ao cobre.

\author{
Rafael Barty Dextro
}

Universidade Federal de São Carlos - UFSCar (Brazil), Rodovia Washington Luiz, km 235,

São Carlos, SP, 13565-905.

*corresponding author: rafaelbdextro@gmail.com

Cite as: Dextro, R. B. Growth dynamic on a co-cultivation of two Chlorophyta microalgae exposed to copper. Acta Limnologica Brasiliensia, 2021, vol. 33, e16.

Abstract: Aim: Copper is an essential nutrient for the phytoplankton, but it can also act as a toxic agent, depending on its concentration. Considering the continuous increase of this metal in the natural aquatic ecosystems, understanding its actions in co-cultivation scenarios is of great relevance. Experiments with the combination of different species resemble more accurately the natural conditions, in contrast of results obtained in single-species tests, which cannot be directly used to describe observed effects on the environment. Methods: Therefore, growth parameters were investigated and compared on the co-cultivation of Chlorella sorokiniana and Kirchneriella obesa and their separate cultures exposed to three different free copper concentrations (control

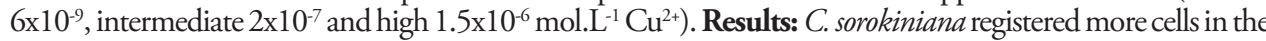
control of the unialgal culture while K. obesa had higher cell density in the control of the co-cultivation. Growth rates decreased with the increment of copper in the unialgal conditions. However, both species maintained a high growth rate in the co-cultivation intermediate copper concentrations. Biovolume varied despite the cultivation method, being strongly related to the metal's concentration. The maximum photosynthetic efficiency decreased in higher copper. Conclusions: According to the results observed, no competitive exclusion occurred and both species were affected by copper in unialgal and co-cultivation conditions, with $K$. obesa being favored by the co-cultivation, which seems to have an attenuation effect on copper toxicity until intermediate concentrations. Ecologically, the results suggest that communities deal better with the toxic effects caused by intermediate copper concentrations than single-species cultures.

Keywords: Chlorophyta; community; metal; microalgae.

Resumo: Objetivo: Cobre é um nutriente essencial para o fitoplâncton, mas ele também pode agir como um agente tóxico, dependendo de sua concentraçăo. Considerando o crescente incremento deste metal em ecossistemas aquáticos naturais, compreender sua ação em cenários de co-cultura é de grande relevância. Experimentos com a combinação de diferentes espécies assemelham-se com maior precisão as condiçóes encontradas na natureza, contrastando com os resultados obtidos em testes unialgais, que não podem ser diretamente usados para descrever efeitos observáveis no ambiente. Métodos: Deste modo, parâmetros de crescimento foram investigados e comparados na co-cultura de Chlorella sorokiniana e Kirchneriella obesa e seus cultivos individuais expostos a três diferentes concentraçôes de cobre livre (controle $6 \times 10^{-9}$, intermediário

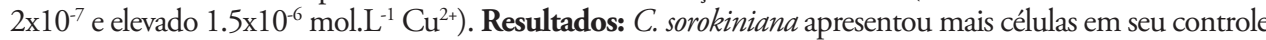
unialgal enquanto $K$. obesa teve maior densidade celular no controle da co-cultura. As taxas de crescimento decairam com o incremento de cobre nas condiçôes unialgais. No entanto, ambas as espécies mantiveram elevada taxa de crescimento na co-cultura em concentraçôes intermediárias do metal. O biovolume variou independentemente do método de cultivo, sendo diretamente relacionado à concentração de cobre. A eficiência fotossintética máxima decaiu sob elevado cobre. Conclusóes: De acordo com os resultados observados, não houve exclusão competitiva e ambas as espécies foram afetadas pelo cobre em condiçôes unialgais ou de cocultura, sendo que $K$. obesa foi favorecida no cultivo em conjunto, que parece apresentar uma atenuaçấo da toxicidade do cobre em concentraçôes intermediárias. Ecologicamente, os resultados sugerem que comunidades lidam melhor com efeitos tóxicos causados por concentraçoes intermediárias de cobre do que culturas isoladas.

Palavras-chave: Chlorophyta; comunidade; metal; microalga. 


\section{Introduction}

Copper is an extremely used metal in various industries, ranging from civil construction to agricultural inputs. Its excessive use has generated a considerable amount of pollution that mainly ends up in water bodies (Shrivastava, 2009). According to the National Council for the Environment (CONAMA) (Brasil, 2005), the class 1 water bodies, intended for protecting aquatic biodiversity, should present a maximum dissolved copper concentration of $1.4 \times 10^{-7} \mathrm{~mol}^{-\mathrm{L}^{-1}}$. In rivers from England's countryside (in good water quality conditions), dissolved copper ranges from $10^{-9}$ to $10^{-7}$ mol.L $L^{-1}$ (Gardner et al., 2000) while rivers that receive mining cupric residues in China present detectable copper concentrations higher than $10^{-4}$ mol.L-1 (Liu et al., 2020), which are considered toxic to most aquatic organisms. Therefore, environmentally relevant dissolved $\mathrm{Cu}$ concentrations can be considered to be below $10^{-7}$ mol.L $\mathrm{L}^{-1}$. The continuous increase of copper in aquatic ecosystems may expose the phytoplankton to concentrations that can cause negative physiological alterations. Reduced photosynthetic yield, increased intracellular reactive oxygen species (ROS) and decreased chlorophyll $a$ synthesis are some metabolic processes triggered by copper (Afkar et al., 2010; Knauert \& Knauer, 2008; Perales-Vela et al., 2007; Pinto et al., 2003).

In the aquatic environments, copper is a natural component that can be found mainly in two distinct forms: particulate and dissolved. The particulate $\mathrm{Cu}$ correspond to the portion in which the metallic ions are associated with other suspended particulate matter, from inorganic (such as clay) to organic (such as decomposing matter) origins (Grassi et al., 2000). This forms colloidal structures that act as the main transporting mechanism of copper in aquatic ecosystems, carrying this metal along the water body or depositing it on the sediment. Most of the copper found in rivers and lakes are in this form $(-70 \%)$, which reduces the bioavailability of $\mathrm{Cu}$ (Windom et al., 1991). The dissolved copper, on the free ionic form of $\mathrm{Cu}^{2+}$, corresponds to the fraction of this metal that microorganisms can quickly interact (Lombardi et al., 2002). For this reason, on this study the free copper concentrations will be measured and used to evaluate the results.

The co-cultivation of microorganisms involves the growth of several species together, mixing bacteria, yeast, cyanobacteria and microalgae in order to create a more realistic scenario of the natural environment. These studies are widespread in the literature of biotechnological fields, either in bioremediation studies or in production of biofuels or biomolecules (Magdouli et al., 2016). The main idea behind co-cultivation is that these organisms all naturally coexist in the environment, already presenting some form of ecological relation. In the ecosystems, they can inhibit each other through allelopathic compounds or favor some other species by releasing metabolites in the media (Chiang et al., 2004; Dunker et al., 2013; Fergola et al., 2007; Nan et al., 2004). In experimental conditions, the co-cultivation may represent the combined work of these organisms enzymatic repertoire, allowing the degradation of complex substrates or increasing lipid production without biomass loss (Arumugam et al., 2014; Liu et al. 2018; Yen et al., 2015; Zhao et al., 2014). Stressful conditions associated with pollutants, nutrient starvation and light intensity are also being studied under co-cultivation conditions hoping to understand synergy mechanisms that allow communities to survive (Antunes et al., 2012; Barreiro \& Hairston, 2013; Granéli \& Johansson, 2003; Oncel et al., 2011).

The effects of growth inhibition between microalgae species and cyanobacteria are well documented. Many species of the Chlorella genus have been described as producers of chlorellin, an antibacterial mix of free fatty acids (Pratt \& Fong, 1940; Spoehr \& Milner, 1949). Other substances related with negative effects on phytoplankton growth that are produced by some microalgae or cyanobacteria are palmitic acid, linoleic acid and $\alpha$-linolenic acid, causing damages to plasmatic membranes and affecting starch deposition on the chloroplasts (Klausner et al., 1980; Pinto et al., 2003). Nonetheless, there are resistant species that can even be stimulated by the presence of others in the same culture media or environment. These synergy mechanisms seems to be sensible and may vary according to specific interspecies relationships (Chiang et al., 2004; Magdouli et al., 2016).

There is a gap in the literature of works investigating metal effects on co-cultivation of microalgae. While bacterial presence on the absence of iron on microalgae cultivation is considerably explored (Kean et al., 2015; Rajapitamahuni et al., 2018) there are no works examining other metals, such as arsenic or copper. Therefore, this study aimed to observe the effects of three distinct copper concentrations on the population dynamics of the co-cultivation of Chlorella sorokiniana Shihira \& R.W. Krauss 1965 and Kirchneriella obesa 
West \& G.S. West 1894. These species, which belong to different classes (Trebouxiophyceae and Chlorophyceae respectively), were chosen due their distinct features, such as presence of a dense mucilage in $K$. obesa, spherical shaped cells in $C$. sorokiniana versus sickle shaped cells in $K$. obesa, distinct copper sensitivities and growth rates. Previous works using the same genera of green microalgae in unialgal conditions exposed to copper reported the sensitivity of Kirchneriella aperta Teiling 1912, which suffered a considerable reduction in growth rate and chlorophyll $a$ production, with $\mathrm{EC}_{50}=-10^{-9} \mathrm{~mol} \cdot \mathrm{L}^{-1}$ free copper (Lombardi et al., 2002). The Chlorella genus seems to be copper resistant, with Chlorella pyrenoidosa $\mathrm{H}$. Chick 1903 displaying a $\mathrm{EC}_{50}$ of $7.5 \times 10^{-7} \mathrm{~mol}^{-\mathrm{L}^{-1}}$ of $\mathrm{Cu}$ (Yan \& Pan, 2002) and Chlorella sp. (at pH 5.7) a $\mathrm{EC}_{50}$ of $5.5 \times 10^{-7}$ mol.L-1 (Franklin et al., 2000). Despite being part of the Chlorella genus, C. sorokiniana has not been described in the literature as a chlorellin producer (Wilde et al., 2006; Zhao et al., 2014). Nonetheless, it grows faster than $K$. obesa, which is larger and produces mucilage, an important structure with ion retention properties that may postpone the toxic effects caused by copper (Lombardi et al., 2002).

\section{Material and Methods}

\subsection{Experimental conditions}

Both microalgae used were cultivated in previously sterilized (autoclave, $20 \mathrm{~min}$ ) normal BG11 media (Rippka et al., 1979) in $1.0 \mathrm{~L}$ polycarbonate bottles containing $400 \mathrm{~mL}$ of media. The initial $\mathrm{pH}$ was adjusted to 7.0 and cultures were illuminated by LED $(2700-3000 \mathrm{~K})$ nourishing $180 \triangle \mathrm{mol}$ photons $\mathrm{m}^{-2} \mathrm{~s}^{-1}$ of photosynthetic active radiation (PAR) at the surface of the culture. Temperature was controlled to $24 \pm 1{ }^{\circ} \mathrm{C}$ and light cycle adjusted for 12:12h. For the experiments, the BG11 medium was prepared without copper, which was later added in all treatments from a commercial mono-elemental pattern for AAS/ICP (1000 $\left.\mathrm{mg} \mathrm{L}^{-1}\right)$ (Sigma-Aldrich, Germany). The microalgae inoculum, cultivated at normal BG11, was only added to the experiment flasks' after the addition of the desired copper concentrations. The inoculum of $K$. obesa was obtained from the Microalgae Culture Collection (CCMA/ strain 345/ WCDM 835) of the Phycology Laboratory, Botanic Department of Universidade Federal de São Carlos (UFSCar) and the inoculum of C. sorokiniana was taken from the Microalgae Bank of the Algal Biotechnology Laboratory (strain 004), Botanic Department of UFSCar.

Before the start of the experiments, both microalgae in exponential growth phase (after 5 days of growth) had their maximum photosynthetic yield $\left(\Phi_{\mathrm{m}}\right)$ measured in order to assess their health condition $\left(\Phi_{\mathrm{m}}=0.7\right.$ or above is considered healthy by Juneau \& Harrison, 2005 and Lombardi \& Maldonado, 2011). Only photosynthetic healthy inocula were used. Experimental cultures grew in $1.0 \mathrm{~L}$ polycarbonate bottles with $400 \mathrm{~mL}$ of BG11 medium. There were three experimental conditions (unialgal C. sorokiniana, unialgal $K$. obesa and co-cultivation) and all of them were exposed to three nominal copper concentrations (control $1.3 \times 10^{-6}$, intermediate $6.5 \times 10^{-6}$ and high $6.5 \times 10^{-5}$ mol. $\mathrm{L}^{-1}$ nominal copper) in triplicates for 6 days. The nominal concentration corresponds to a theoretical amount of a substance when preparing a solution. Therefore, all the results on this study were analyzed according to free copper concentrations, determined with an ion-selective electrode, corresponding more realistically to the bioavailable $\mathrm{Cu}$ present in the culture media. The control concentration represents the normal amount of copper used in the BG-11 formulation, the intermediate is a 5-fold increment and the high condition is a 50-fold increase. These concentrations were selected to represent a rising environmental gradient of copper and were based on values that can positively affect growth and photosynthesis of microalgae, as observed in the results of Lombardi et al. (2002). All experimental groups received an inoculum of $5 \times 10^{4}$ cells $\mathrm{mL}^{-1}$ but for the co-cultivation it was used a 1:1 ratio inoculum of each species, which represent a double initial cell abundance compared to single species cultures. All bottles used were previously washed with $\mathrm{HNO}_{3} 1.0 \mathrm{~mol} \mathrm{~L}^{-1}$ for 7 days in order to assure metal removal. Afterwards, they were rinsed with milli-Q water and autoclaved with culture medium. Only plastic or Teflon materials were used, all previously washed for $24 \mathrm{~h}$ in $\mathrm{HCl} 1.0 \mathrm{~mol} \mathrm{~L}^{-1}$ and rinsed in milli-Q water.

\subsection{Copper determination}

Free copper ions present in the culture media were determined prior to microalgae inoculation using an ion-selective copper electrode (Orion, model 94-29) and a double junction reference electrode. During the readings, temperature was maintained constant $\left(22 \pm 2^{\circ} \mathrm{C}\right)$ and metallic buffers were used to extend the linear amplitude 
of the calibration curve up to $10^{-10} \mathrm{~mol} \mathrm{~L}^{-1} \mathrm{Cu}^{2+}$. All metallic solutions used were kept in plastic recipients, which were previously washed in $\mathrm{HNO}_{3} 1.0 \mathrm{~mol} \mathrm{~L}^{-1}$ for $48 \mathrm{~h}$ and rinsed in milli-Q water. To make the calibration curve, triplicates of 6 known copper concentrations (ranging from $10^{-5}$ to $10^{-7} \mathrm{~mol} \mathrm{~L}^{-1}$ ) were used, plus the metallic buffer. Using the linear equation obtained, it was possible to estimate the free copper concentration of $50 \mathrm{~mL}$ samples of each experimental condition, which had their ionic strength adjusted to $0.02 \mathrm{~mol} \mathrm{~L}^{-1}$ using high purity $\mathrm{NaNO}_{3}$ (SigmaAldrich, Germany), by reading their potential $(\mathrm{mV})$. The free copper determinations were performed in a clean room with positive pressure given by horizontal filtered air flow. As expect due the presence of EDTA (chelating agent) in the BG11 medium, the nominal copper values used resulted in different final free copper concentrations (control $6 \times 10^{-9}$, intermediate $2 \times 10^{-7}$ and high $1.5 \times 10^{-6}$ mol. $\left.\mathrm{L}^{-1} \mathrm{Cu}^{2+}\right)$. All results were discussed based on these estimated free copper concentrations, since this form of the metal correspond to the ionic form that is absorbed by cells (bioavailable) or complexed by molecules.

\subsection{Population dynamics}

Samples were taken daily for two purposes: cell count, performed manually in an optic microscope (Nikon Eclipse E200, Japan) and to determine the fluorescence in vivo of chlorophyll a $\left(\mathrm{mg} \mathrm{L}^{-1}\right)$ using a fluorimeter (Turner Designs AU-10, Trilogy, US). A calibration curve was made considering the chlorophyll $a$ extracted from a C. sorokiniana culture in exponential phase in several concentrations versus the in vivo chlorophyll $a$ fluorescence of this same culture. The extraction of the pigment followed the protocol described in Jeffrey and Humphrey (1975). The curve was adjusted in its linear portion and the equation was used to calculate the chlorophyll $a$ concentration of each sample.

Specific growth rates $\left(\mathbb{\|}, \mathrm{d}^{-1}\right)$ were obtained as being the inclination of a linear regression of the exponential growth phase, traced as the natural logarithm of cell density (cells $\mathrm{mL}^{-1}$ ) versus experimental time in days (Silva et al., 2018). Biovolume $\left(\Delta \mathrm{m}^{3}\right)$ was calculated for both species in all experimental conditions at $72 \mathrm{~h}$ of growth, measuring at least 50 cells under the optic microscope using a Fuchs-Rosenthal counting chamber. Each species had a specific equation for cell volume, as proposed by Hillebrand et al. (1999).

\subsection{Photosynthetic measure}

The maximum photosynthetic yield of the photosystem II (PSII) was determined daily using a Pulse-Amplitude-Modulation (PAM) chlorophyll fluorometer (Phyto-PAM, Heinz Walz GmbH, Germany), which applies a saturating light pulse in a $3 \mathrm{~mL}$ aliquot of the culture previously adapted to darkness $(20 \mathrm{~min})$. This previous acclimation without light is essential to maintain all reaction centers of the photosystem II (PSII) open, with the primary electron acceptor $Q_{A}$ at its oxidized state. When the Phyto-PAM emits a short duration saturating pulse of light, the $Q_{A}$ acceptors are all reduced, closing the reaction centers. At this moment, the maximum fluorescence is captured by the fluorometer, representing the maximum photosynthetic yield $\left(\Phi_{\mathrm{m}}\right)$.

For unialgal cultures, the measurements represent the maximum photosynthetic yield of each species, using the logistic parameters determined by Juneau et al. (2002) for microalgae. The results presented for $\Phi_{\mathrm{m}}$ of the co-cultivation represents a total fluorescence value emitted by the mixture of species.

\subsection{Statistical analyses}

The results were examined through a normality test (Shapiro-Wilk) in order to select accurate statistical analyzes based on the data's normal tendency. Afterwards, the results for copper per cell, growth rate and biovolume were analyzed through a simple ANOVA with a confidence interval of 95\% to detect differences between the means of each copper concentration tested in relation to the control, using the Statistical Assistance software (ver. 7.7) for Windows.

The significantly statistical differences were marked with asterisks in all graphs, which were made using IgorPro 6.0.5 (WaveMetrics, USA). For copper per cell, each copper concentration (intermediate and high) had statistically noteworthy responses as the metal concentration increased. In the growth rate analyzes, the ANOVA showed that the highest copper tested generated statistical difference in both microalgae for both cultivation conditions. Additionally, C. sorokiniana and K. obesa also presented a significant result $(\mathrm{p}<0.05)$ at unialgal conditions for intermediate copper. Finally, for biovolume, a similar trend happened, with the significant differences occurring at higher copper concentrations for both species and solely for C. sorokiniana unialgal cultivation at intermediate copper. 


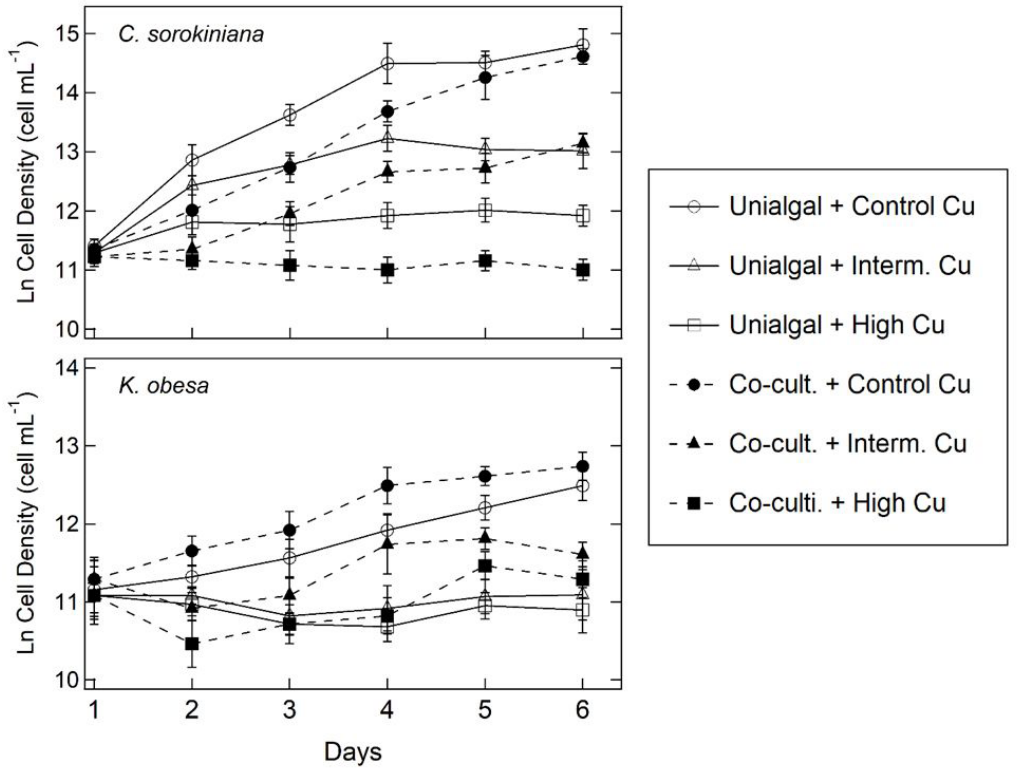

Figure 1. Population density (Ln cell $\mathrm{mL}^{-1}$ ) of Chlorella sorokiniana (up) and Kirchneriella obesa (down) in unialgal conditions (continuous line, unfilled symbols) and co-cultivation (dashed line, filled symbols) as a function of experimental period in days with mean \pm standard deviation. Copper concentration symbols: circle (control, $6 \times 10^{-9} \mathrm{~mol} \mathrm{~L}^{-1}$ ), triangle (intermediate, $2 \times 10^{-7} \mathrm{~mol} \mathrm{~L}^{-1}$ ) and square (high, $1.5 \times 10^{-6} \mathrm{~mol} \mathrm{~L}^{-1}$ ).

\section{Results}

The population density (cells $\mathrm{mL}^{-1}$ ) of C. sorokiniana and $K$. obesa at co-cultivation and at the unialgal conditions as a function of experimental period (Figure 1) shows that $C$. sorokiniana reached higher cell number at the control of the singlespecies culture. The same trend was observed for the other copper conditions. K. obesa presented greater cell density at the co-cultivation with less copper (control, 6x10 $0^{-9} \mathrm{~mol} \mathrm{~L}^{-1} \mathrm{Cu}^{2+}$ ). On the intermediate and high concentrations of the metal, the co-cultivation condition registered more $K$. obesa cells than its unialgal culture exposed to the same copper concentration.

In order to assess the average amount of copper each cell was exposed to at the moment of inoculation (day 1), it was calculated the free copper concentration per cell of each experimental treatment (Figure 2). It is noticeable that since the co-cultivation had more cells, each cell was potentially exposed to less copper than those in the unialgal cultures, especially in the intermediate and high copper concentrations, were the variation observed was statistically significant.

The increment of copper in the culture media caused an overall decrease in chlorophyll $a$ concentrations $\left(\bigotimes \mathrm{g} \mathrm{mL}^{-1}\right)$, as observed in Figure 3. The highest value of chlorophyll $a$ was obtained in the single-species cultivation of $C$. sorokiniana at the control, whereas all the other treatments

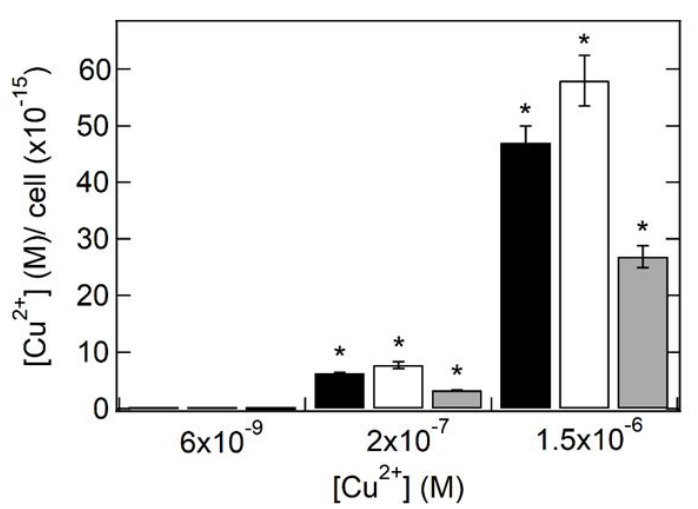

Figure 2. Free copper concentration per cell of Chlorella. sorokiniana (घ), Kirchneriella obesa ( $\square$ ) and co-cultivation (a) as a function of the three copper concentrations tested. Error bars represent the mean \pm standard deviation. The symbol ${ }^{*}$ represents statistically significant difference $(\mathrm{p}<0.05)$ regarding the control.

(both unialgal and co-cultivation) exposed to $1.5 \times 10^{-6} \mathrm{~mol} \mathrm{~L}^{-1} \mathrm{Cu}^{2+}$ (high copper condition) registered chlorophyll $a$ concentrations lower than $0.1 \otimes g \mathrm{~mL}^{-1}$.

Copper has affected the growth rate of both species tested, causing a more intense reduction at the unialgal conditions (Figure 4). While in cocultivation the intermediate copper concentration $\left(2 \times 10^{-7} \mathrm{~mol} \mathrm{~L}^{-1} \mathrm{Cu}^{2+}\right)$ did not caused a significant reduction $(\mathrm{p}<0.05)$, at the single-species cultures there was a decrease of $55 \%$ and $65 \%$ on the growth rates of $C$. sorokiniana and $K$. obesa in relation to the 

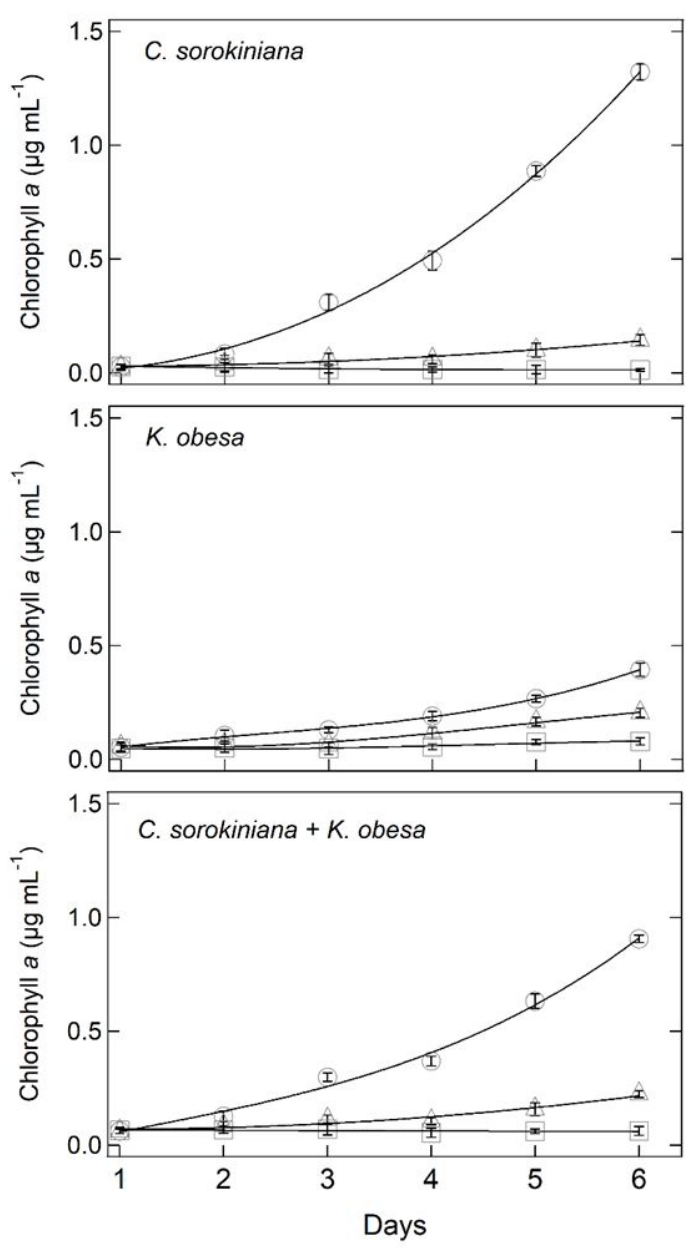

Figure 3. Chlorophyll $a(\nabla \mathrm{g} \mathrm{mL}-1)$ of Chlorella sorokiniana (up), Kirchneriella obesa (middle) and co-cultivation (down) as a function of experimental period in days with mean \pm standard deviation. Copper concentration symbols: $\bigcirc$ (control, $6 \times 10^{-9} \mathrm{~mol} \mathrm{~L}^{-1}$ ), $\triangle$ (intermediate, $\left.2 \times 10^{-7} \mathrm{~mol} \mathrm{~L}^{-1}\right)$ and $\square$ (high, $\left.1.5 \times 10^{-6} \mathrm{~mol} \mathrm{~L}^{-1}\right)$.

unialgal control. At the high copper concentration $\left(1.5 \times 10^{-6} \mathrm{~mol} \mathrm{~L}^{-1} \mathrm{Cu}^{2+}\right)$ all treatments registered significant reductions on growth of unialgal $(95 \%$ for C. sorokiniana and $80 \%$ for $K$. obesa) and co-cultivation conditions $(90 \%$ for C. sorokiniana and $-60 \%$ for $K$. obesa).

The biovolume (Figure 5) increased significantly $(\mathrm{p}<0.05)$ at the highest copper concentration tested in both single-species and co-cultivation conditions. Cell enlargement observed was of almost 3-fold in C. sorokiniana and $-30 \%$ in $K$. obesa when considering control versus high copper treatments.

The maximum photosynthetic yield $\left(\Phi_{\mathrm{m}}\right)$ of all copper treatments on the single-species $K$. obesa culture registered values above 0.65 (Figure 6 ). In the co-cultivation, the control and the intermediate concentration $\left(2 \times 10^{-7} \mathrm{~mol} \mathrm{~L}^{-1} \mathrm{Cu}^{2+}\right)$ presented a slight drop on the $\Phi_{\mathrm{m}}$ during the experiment, but
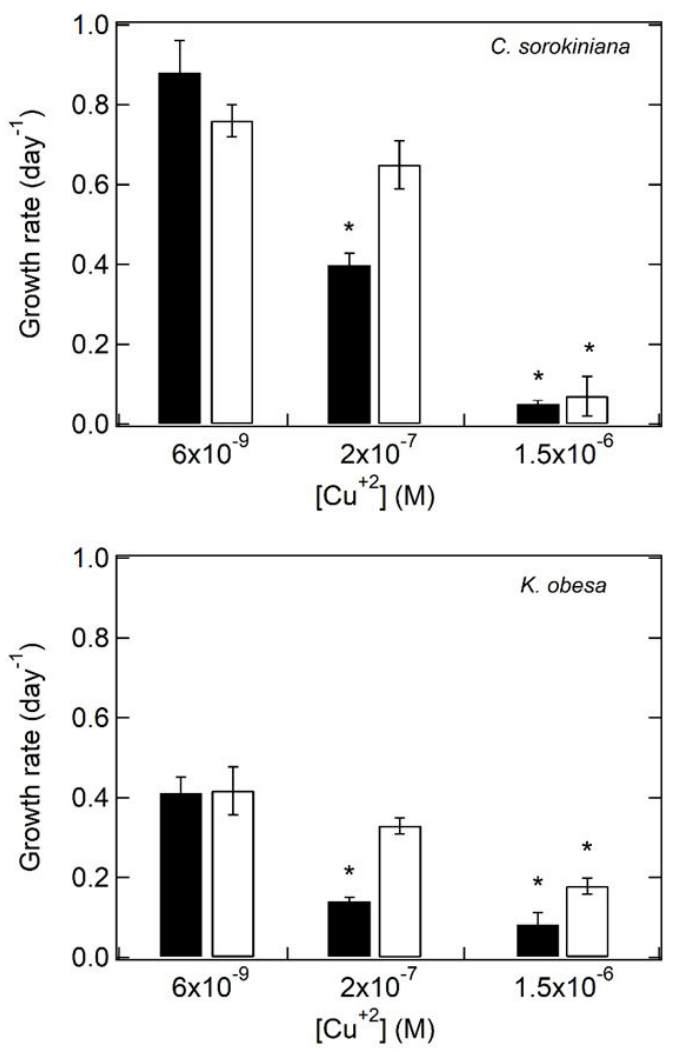

Figure 4. Growth rate $\left(\mathrm{d}^{-1}\right)$ of Chlorella sorokiniana (up) and Kirchneriella obesa (down) in unialgal conditions (black bars) and co-cultivation (white bars) as a function of the copper concentrations tested with mean \pm standard deviation. The symbol ${ }^{*}$ represents statistically significant difference $(\mathrm{p}<0.05)$ regarding the control.

remained $\geq 0.6$. The higher copper concentration tested caused significant reduction on the maximum photosynthetic yield on the co-cultivation and on the unialgal $C$. sorokiniana culture, with values < 0.6 on both conditions.

\section{Discussion}

Comparing growth patterns of the microalgae species tested, it is possible to observe that C. sorokiniana had higher cell concentration in unialgal conditions compared to co-cultivation for all copper concentrations tested, during most of the experiment. Conversely, K. obesa had lower cell count at unialgal compared to co-cultivation for all copper conditions tested. However, at the last day of the experiment, cell concentration was similar in both unialgal and co-cultivation conditions at the control copper, which resulted in similar growth rates for both species. It is common to observe in cocultivation a limitation on growth, since it is believed that each species competes for light and nutrients, which takes them away from their optimum growth 

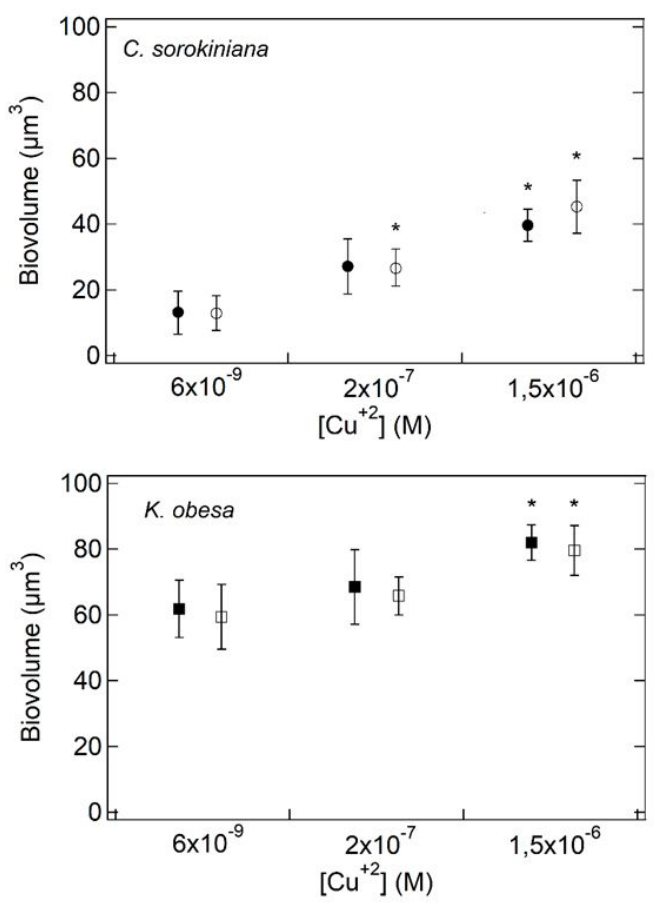

Figure 5. Biovolume $\left(\triangle \mathrm{m}^{3}\right)$ of Chlorella sorokiniana (up) and Kirchneriella obesa (down) in unialgal conditions (black symbols) and co-cultivation (white symbols) measured after $72 \mathrm{~h}$ of growth as a function of all three copper concentrations tested with mean \pm standard deviation. The symbol ${ }^{*}$ represents statistically significant difference $(\mathrm{p}<0.05)$ regarding the control.

conditions (Fergola et al., 2007; Nan et al., 2004). The culture medium used, BG11, is a nutrient rich medium. Additionally, since the experiment only lasted for 6 days, it is expected that nutritional limitations on growth were prevented. Another aspect discussed in the literature is the production of allelopathic agents that inhibit the growth of several microorganisms according to their specific sensibilities (Chiang et al., 2004; Zhao et al., 2014). The genus Chlorella is well known for its chlorellin production, particularly the species $C$. vulgaris Beyerinck 1890 (Pratt et al., 1944; Dellagreca et al., 2010). However, C. sorokiniana has not been reported as a chlorellin producer. In this study, $K$. obesa was not negatively affected by the presence of $C$. sorokiniana, leading to the conclusion that chlorellin was not produced, its concentration in the culture was not high enough to cause and impact on $K$. obesa or this species is resistant to this type of allelopathy. Many elements should be taken into account regarding these two species interactions, such as differences in metabolic activity, distinct cell sizes, presence of a mucilaginous capsule in $K$. obesa and a disparity in the growth rates of these species. Dellagreca et al. (2010) observed
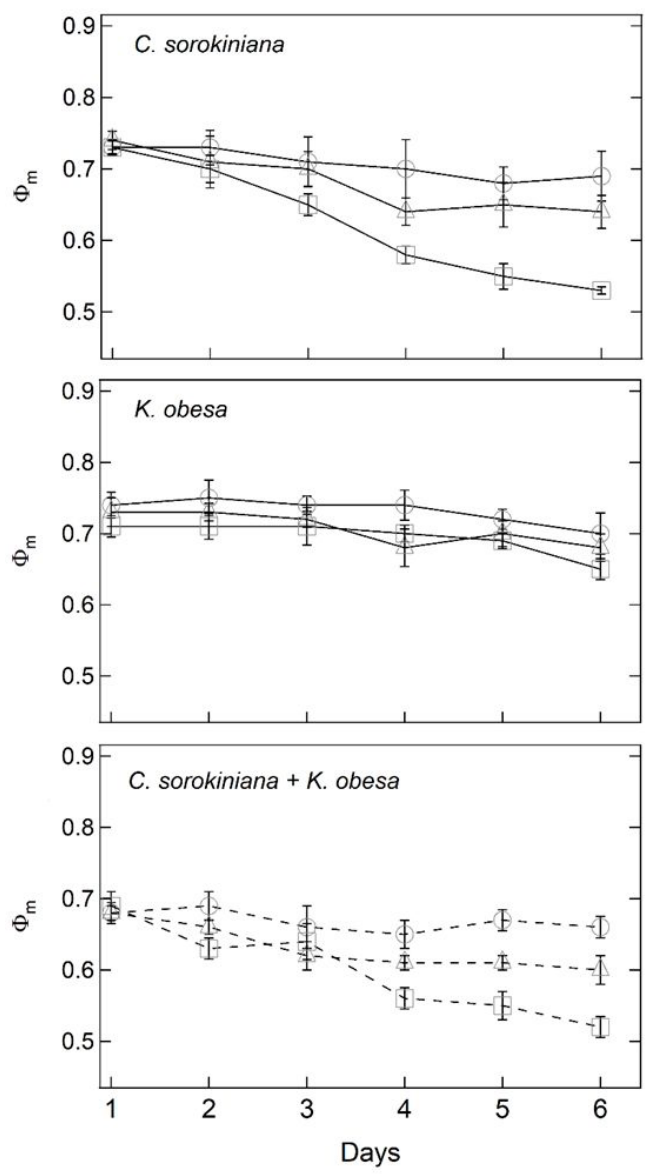

Figure 6. Maximum photosynthetic yield $\left(\Phi_{\mathrm{m}}\right)$ of Chlorella sorokiniana (up), Kirchneriella obesa (middle) and cocultivation (down) as a function of experimental period in days with mean \pm standard deviation. Copper concentration symbols: $\bigcirc$ (control, $\left.6 \times 10^{-9} \mathrm{~mol} \mathrm{~L}^{-1}\right), \triangle$ (intermediate, $2 \times 10^{-7} \mathrm{~mol} \mathrm{~L}^{-1}$ ) and $\square$ (high, $1.5 \times 10^{-6} \mathrm{~mol} \mathrm{~L}^{-1}$ )

a stimulus in growth on the co-cultivation of Pseudokirchneriella subcapitata F. Hindák 1990 and C. vulgaris when exposed to filtered culture medium containing low amounts of free fatty acids and chlorellin $\left(<3.2 \mathrm{mg} \mathrm{L}^{-1}\right)$. Nonetheless, in higher concentrations of chlorellin $\left(>26 \mathrm{mg} \mathrm{L}^{-1}\right.$ ), both species were affected, with $P$. subcapitata showing an extreme sensibility. Microalgae in co-cultivation are capable of altering the metabolism and synthesis of biomolecules of each another through substances released extracellularly, especially in exponential and stationary growth phases. These substances may cause inhibition or stimulation on the species present, depending on the concentration of the biomolecules and species-specific sensibility (Dunker et al., 2013; Magdouli et al., 2016; Oncel et al., 2011).

Adding to this mixture and the stressful factor of a metal such as copper, the interspecific relations 
of $C$. sorokiniana and $K$. obesa were reflected on their growth parameters. In the intermediate copper concentration $\left(2 \times 10^{-7} \mathrm{~mol} \mathrm{~L}^{-1} \mathrm{Cu}^{2+}\right)$ both species maintained their growth rates observed in the control $(\mathrm{p}<0.05)$, with values higher than those observed in the unialgal cultures exposed to the same copper concentration. Sanders and Cibik (1988) argue that communities can thrive depending on their species composition and type of contaminant studied. In their research, they observed that arsenic was detrimental to the community, reducing cell sizes and the nutritional value of the plankton, while silver caused a positive swift in the overall diversity. On the present study, the maintenance of growth rates in intermediate and control copper concentrations for both species at co-cultivation shows that the combined metabolic capacity of the species tested may allow them to resist this toxic metal together at these specific concentrations. Many researchers investigate the absence of iron in co-cultivations, showing that the presence of siderophore-producing bacteria, which liberates iron-chelating compounds with high affinity in the medium, contributes to the survival and stimulates growth in microalgae (Kean et al., 2015; Keshtacher-Liebso et al., 1995; Rajapitamahuni et al., 2018). Conversely, results discussing the effects of other metals are scarce. Some of the stress agents commonly tested are light and nutrients. Antunes et al. (2012) tested the effects of Cylindrospermopsis raciborskii Seenayya \& S. Raju 1972 (a producer of cylindrospermopsin) on Ankistrodesmus falcatus Ralfs 1848. In the cocultivation, $A$. falcatus displayed reduction on biovolume and growth rate, which could be worsen by higher light intensity and medium alkalization. Oppositely, this study observed a reduction of the overall stressful effects of copper in intermediate concentrations of the co-cultivation in comparison to the single-species conditions. This may be related to the production of several extracellular agents with chelating functions, such as polysaccharides (Pistocchi et al., 1997) or metal-binding proteins (Sabatini et al., 2009), what may diminish the bioavailability of copper in the culture medium. At the highest copper concentration tested all growth parameters were affected, in co-cultivation and unialgal conditions, representing the toxic effects of copper in microalgae's metabolism.

It is important to highlight the differences in initial cell density between single-species cultures and co-cultivation (Figure 3) and how it may partially explain the results obtained. The greater amount of cells at the co-cultivation on the first day of experiment predicts that the cells are potentially exposed to less copper ions than unialgal cultures. Therefore, an attenuation effect on the metal's toxicity cannot be forwent. Despite this cell density difference, other factors may influence metal speciation and bioavailability in culture media, such as physicochemical aspects ( $\mathrm{pH}$ and temperature), chemical and polarity affinity to other molecules and the presence of exudates with chelating properties, which have been described to be released by microalgae (Pistocchi et al., 1997; Sabatini et al., 2009).

The effects of copper in the physiology of microalgae are well-known in the literature for a great variety of species. The reduction on cell density and drop on growth rates are associated with direct effects of copper in the photosynthetic apparatus of the microalgae, whereas indirect effects include the production of ROS, damages to plasmatic membranes and intracellular ultrastructure (Angel et al., 2017; Jiang et al., 2001; Tripathi et al., 2006). The reduction on chlorophyll $a$ observed in this study on both single and joint cultures of $C$. sorokiniana and $K$. obesa are most likely related to the toxic action of copper on the synthesis of pigments (Perales-Vela et al., 2007; Pinto et al., 2003). The increment in biovolume, which can be interpreted as an inability to divide and a survival strategy to copper due the alteration between the surface-volume ratio that reduces the cell exposure to copper ions (Echeveste et al., 2017; Machado \& Soares, 2014), also expresses a consequence of the toxicity of copper rather than possible co-cultivation induced effects. Nevertheless, $K$. obesa had its growth favored at co-cultivation, which can be related to its greater cell size and presence of mucilage. These features may have given an extra protection to this species in the detriment of C. sorokiniana's growth. Another possible scenario would be the accumulation on the extracellular environment of exopolysaccharides and metal-binding proteins from both species, helping both of them to resist the intermediate copper concentration together, maintaining their growth rates, differently from the single-species cultures were this copper concentration was enough to cause cell density and growth rate reductions.

In a general sense, it is argued that microalgae co-cultivation can have positive and negative effects on the culture and that these effects are intrinsically related to the species used and their possible ecological relations in natural environments 
(Dunker et al., 2013; Fergola et al., 2007; Zhao et al., 2014). In this study, C. sorokiniana and $K$. obesa did not show antagonist relations at their joint growth condition. However, when analysing the maximum photosynthetic yield of the co-cultivation it is remarkable that the values observed were in general inferior to those obtained in the separate cultures, especially the control copper concentration. In this condition copper was not a stressful factor, so this small reduction on the overall photosynthesis performance can be attributed to a possible light limitation effect caused by self-shading due to the presence of more cells in the medium (Magdouli et al., 2016). As expected, copper reduced the maximum photosynthetic yield in all treatments exposed to $2 \times 10^{-7}$ and $1.5 \times 10^{-6} \mathrm{~mol} \mathrm{~L}^{-1} \mathrm{Cu}^{2+}$, with the co-cultivation and the unialgal culture of $C$. sorokiniana presenting the lower mean values (below 0.7 at the third day of experiment). $\Phi_{\mathrm{m}}$ is a parameter that varies according to each species sensibility and, generally, shows the photosynthetic apparatus health in conditions $>0.7$ (Juneau \& Harrison, 2005; Lombardi \& Maldonado, 2011). Therefore, copper affected the photosynthesis of these microalgae, reducing their maximum photosynthetic yields probably acting specifically in molecules such as plastoquinone and plastocyanin, both essential electron transporters between PSII and PSI and that have already been described as susceptible to damages mediated by copper (Knauert \& Knauer, 2008; Mallick \& Mohn, 2003; Mohanty et al., 1989).

C. sorokiniana and $K$. obesa were affected by copper in both culture condition tested (singlespecies or co-cultivation). The joint-cultivation caused distinct responses in these species, favoring the growth of $K$. obes $a$ and reducing the toxic effects of copper in the intermediate copper concentration tested $\left(2 \times 10^{-7} \mathrm{~mol} \mathrm{~L}^{-1} \mathrm{Cu}^{2+}\right)$, in which the decrease in cell density and growth rates occurred less intensively than the reduction observed in the unialgal cultures $(p<0.05)$. Copper, without a clear relation with the separate or joint cultivation, altered the biovolume of both species. Additionally, it was observed that copper affects the photosynthesis of microalgae in a species-specific way, with some species being more sensitive to the damage mediated by copper than others. The effects detected in this study on the growth and photosynthesis parameters are responses induced by copper in unialgal cultures of $C$. sorokiniana and $K$. obesa and their co-cultivation, which did not present competitive exclusion between the species tested. Despite that,
$K$. obesa was favored by the joint growth condition while $C$. sorokiniana suffered a reduction in cell density when compared to its unialgal growth. The presence of mucilage and different cell sizes may have been important factors related to the behavior observed in co-cultivation and could partially explain the results obtained. Additional research, testing other species and including more copper damage assessment parameters (such as production of antioxidants) can deepen the knowledge around copper effects in microalga communities. From an ecological point of view, this research strengthens the argument that in natural conditions, with species co-exiting, the community as a whole can deal differently with stressful factors such as metals concentrations, surviving and growing better than each individual species would separately.

\section{Acknowledgements}

This research was funded by grants received from Conselho Nacional de Desenvolvimento Científico e Tecnológico (CNPq) (302175/2015-6; 830792/1999-6; 132551/2017-9) and São Paulo Research Foundation (FAPESP) (2018/07988-5). The author would also like to thank and acknowledge Professor Ana Teresa Lombardi, coordinator of the Algal Biotechnology Laboratory, Botanic Department of Universidade Federal de São Carlos (UFSCar), for the support on providing materials and space in which this research was performed.

\section{References}

AFKAR, E., ABABNA, H. and FATHI, A.A. Toxicological response of the green alga Chlorella vulgaris, to some heavy metals. American Journal of Environmental Sciences, 2010, 6(3), 230-237. http:// dx.doi.org/10.3844/ajessp.2010.230.237.

ANGEL, B.M., SIMPSON, S.L., GRANGER, E., GOODWYN, K. and JOLLEY, D.F. Time-averaged concentrations are effective for predicting chronic toxicity of varying copper pulse exposures for two freshwater green algae species. Environmental Pollution, 2017, 230, 787-797. http://dx.doi.org/10.1016/j. envpol.2017.07.013. PMid:28734260.

ANTUNES, J.T., LEÃO, P.N. and VASCONCELOS, V.M. Influence of biotic and abiotic factors on the allelopathic activity of the cyanobacterium Cylindrospermopsis raciborskii strain LEGE 99043. Microbial Ecology, 2012, 64(3), 584-592. http://dx.doi.org/10.1007/s00248-012-0061-7. PMid:22562107.

ARUMUGAM, A., SANDHYA, M. and PONNUSAMI, $\mathrm{V}$. Biohydrogen and polyhydroxyalkanoate coproduction by Enterobacter aerogenes and Rhodobacter 
sphaeroides from Calophyllum inophyllum oil cake. Bioresource Technology, 2014, 164, 170-176. http://dx.doi.org/10.1016/j.biortech.2014.04.104. PMid:24859207.

BARREIRO, A. and HAIRSTON, N.G. Jr. The influence of resource limitation on the allelopathic effect of Chlamydomonas reinhardtii on other unicellular freshwater planktonic organisms. Journal of Plankton Research, 2013, 35(6), 1339-1344. http:// dx.doi.org/10.1093/plankt/fbt080.

BRASIL. Ministério do Meio Ambiente. Conselho Nacional do Meio Ambiente - CONAMA. Resolução n 357, 17 de março de 2005. Dispóe sobre a classificação dos corpos de água e diretrizes ambientais para o seu enquadramento, bem como estabelece as condiçóes e padróes de lançamento de efluentes, e dá outras providências. Diário Oficial da Uniấo [da] República Federativa do Brasil, Poder Executivo, Brasília, DF, 18 mar. 2005, pp. 7-8.

CHIANG, I.Z., HUANG, W.Y. and WU, J.T. Allelochemicals of Botryococcus brannii (hlorophyceae). Journal of Phycology, 2004, 40(3), 474-480. http:// dx.doi.org/10.1111/j.1529-8817.2004.03096.x.

DELLAGRECA, M., ZARRELLI, A., FERGOLA, P., CERASUOLO, M., POLLIO, A. and PINTO, G. Fatty acids released by Chlorella vulgaris and their role in interference with Pseudokirchneriella subcapitata: experiments and modelling. Journal of Chemical Ecology, 2010, 36(3), 339-349. http://dx.doi. org/10.1007/s10886-010-9753-y. PMid:20186470.

DUNKER, S., JAKOB, T. and WILHELM, C. Contrasting effects of the cyanobacterium Microcystis aeruginosa on the growth and physiology of two green algae, Oocystis marsonii and Scenedesmus obliquus, revealed by flow cytometry. Freshwater Biology, 2013, 58(8), 1573-1587. http://dx.doi.org/10.1111/ fwb. 12143 .

ECHEVESTE, P., SILVA, J.C. and LOMBARDI, A.T. $\mathrm{Cu}$ and $\mathrm{Cd}$ affect distinctly the physiology of a cosmopolitan tropical freshwater phytoplankton. Ecotoxicology and Environmental Safety, 2017, 143, 228-235. http://dx.doi.org/10.1016/j. ecoenv.2017.05.030. PMid:28551580.

FERGOLA, P., CERASUOLO, M., POLLIO, A., PINTO, G. and DELLAGRECA, M. Allelopathy and competition between Chlorella vulgaris and Pseudokirchneriella subcapitata: experiments and mathematical model. Ecological Modelling, 2007, 208(2-4), 205-214. http://dx.doi.org/10.1016/j. ecolmodel.2007.05.024.

FRANKLIN, N.M., STAUBER, J.L., MARKICH, S.J. and LIM, R.P. pH-dependent toxicity of copper and uranium to a tropical freshwater alga (Chlorella sp.). Aquatic Toxicology (Amsterdam, Netherlands), 2000, 48(2-3), 275-289. http://dx.doi.org/10.1016/S0166445X(99)00042-9. PMid:10686332.
GARDNER, M., DIXON, E. and COMBER, S Copper complexation in English rivers. Chemical Speciation and Bioavailability, 2000, 12(1), 1-8. http://dx.doi.org/10.3184/095422900782775571.

GRANÉLI, E. and JOHANSSON, N. Increase in the production of allelopathic substances by Prymnesium parvum cells grown under $\mathrm{N}$-or P-deficient conditions. Harmful Algae, 2003, 2(2), 135-145. http://dx.doi.org/10.1016/S15689883(03)00006-4.

GRASSI, M.T., SHI, B. and ALLEN, H.E. Partition of copper between dissolved and particulate phases using aluminum oxide as an aquatic model phase: effects of $\mathrm{pH}$, solids and organic matter. Journal of the Brazilian Chemical Society, 2000, 11(5), 516-524. http:// dx.doi.org/10.1590/S0103-50532000000500014.

HILLEBRAND, H., DÜRSELEN, C.D., KIRSCHTEL, D., POLLINGHER, U. and ZOHARY, T. Biovolume calculation for pelagic and benthic microalgae. Journal of Phycology, 1999, 35(2), 403-424. http://dx.doi.org/10.1046/j.15298817.1999.3520403.x.

JEFFREY, S.W. and HUMPHREY, G.F. New spectrophotometric equations for determining chlorophylls a, b, c1 and c2 in higher plants, algae and natural phytoplankton. Biochemistry and Physiology of Plants, 1975, 167(2), 191-194. http://dx.doi. org/10.1016/S0015-3796(17)30778-3.

JIANG, W., LIU, D. and LIU, X. Effects of copper on root growth, cell division, and nucleolus of Zea mays. Biologia Plantarum, 2001, 44(1), 105-109. http:// dx.doi.org/10.1023/A:1017982607493.

JUNEAU, P. and HARRISON, P.J. Comparison by PAM Fluorometry of Photosynthetic Activity of Nine Marine Phytoplankton Grown Under Identical Conditions. Photochemistry and Photobiology, 2005, 81(3), 649-653. http://dx.doi.org/10.1562/2005-0113-RA-414.1. PMid:15686444.

JUNEAU, P., EL BERDEY, A. and POPOVIC, R. PAM Fluorometry in the determination of the sensitivity of Chlorella vulgaris, Selenastrum capricornutum and Chlamydomonas reinhardtii to copper. Archives of Environmental Contamination and Toxicology, 2002, 42(2), 155-164. http://dx.doi.org/10.1007/s00244001-0027-0. PMid:11815806.

KEAN, M.A., DELGADO, E.B., MENSINK, B.P. and BUGTER, M.H.J. Iron chelating agents and their effects on the growth of Pseudokirchneriella subcapitata, Chlorella vulgaris, Phaeodactylum tricornutum and Spirulina platensis in comparison to Fe-EDTA. Journal of Algal Biomass Utilization, 2015, 6, 56-73.

KESHTACHER-LIEBSO, E., HADAR, Y. and CHEN, Y. Oligotrophic bacteria enhance algal growth under iron-deficient conditions. Applied and Environmental Microbiology, 1995, 61(6), 2439-2441. http:// 
dx.doi.org/10.1128/AEM.61.6.2439-2441.1995. PMid: 16535058.

KLAUSNER, R.D., KLEINFELD, A.M., HOOVER, R.L. and KARNOVSKY, M.J. Lipid domains in membranes. Evidence derived from structural perturbations induced by free fatty acids and lifetime heterogeneity analysis. The Journal of Biological Chemistry, 1980, 255(4), 1286-1295. http:// dx.doi.org/10.1016/S0021-9258(19)86027-1. PMid:7354027.

KNAUERT, S. and KNAUER, K. The role of reactive oxygen species in copper toxicity to two freshwater green algae. Journal of Phycology, 2008, 44(2), 311-319. http://dx.doi.org/10.1111/j.15298817.2008.00471.x. PMid:27041187.

LIU, J., WU, J., FENG, W. and LI, X. Ecological Risk Assessment of Heavy Metals in Water Bodies around Typical Copper Mines in China. International Journal of Environmental Research and Public Health, 2020, 17(12), 4315. http://dx.doi.org/10.3390/ ijerph17124315. PMid:32560327.

LIU, L., CHEN, J., LIM, P.E. and WEI, D. Dual-species cultivation of microalgae and yeast for enhanced biomass and microbial lipid production. Journal of Applied Phycology, 2018, 30(6), 1-11. http://dx.doi. org/10.1007/s10811-018-1526-y.

LOMBARDI, A.T. and MALDONADO, M.T. The effects of copper on the photosynthetic response of Phaeocystis cordata. Photosynthesis Research, 2011, 108(1), 77-87. http://dx.doi.org/10.1007/s11120011-9655-z. PMid:21519899.

LOMBARDI, A.T., VIEIRA, A.A. and SARTORI, L.A. Mucilaginous capsule adsorption and intracellular uptake of copper by Kirchneriella aperta (Chlorococcales). Journal of Phycology, 2002, 38(2), 332-337. http://dx.doi.org/10.1046/j.15298817.2002.00126.x.

MACHADO, M.D. and SOARES, E.V. Modification of cell volume and proliferative capacity of Pseudokirchneriella subcapitata cells exposed to metal stress. Aquatic Toxicology (Amsterdam, Netherlands), 2014, 147, 1-6. http://dx.doi.org/10.1016/j. aquatox.2013.11.017. PMid:24342441.

MAGDOULI, S., BRAR, S.K. and BLAIS, J.F. Coculture for lipid production: advances and challenges. Biomass and Bioenergy, 2016, 92, 20-30. http:// dx.doi.org/10.1016/j.biombioe.2016.06.003.

MALLICK, N. and MOHN, F.H. Use of chlorophyll fluorescence in metal-stress research: a case study with the green microalga Scenedesmus. Ecotoxicology and Environmental Safety, 2003, 55(1), 64-69. http://dx.doi.org/10.1016/S0147-6513(02)00122-7. PMid:12706394.

MOHANTY, N., VASS, I. and DEMETER, S. Copper toxicity affects photosystem II electron transport at the secondary quinone acceptor, QB. Plant
Physiology, 1989, 90(1), 175-179. http://dx.doi. org/10.1104/pp.90.1.175. PMid:16666731.

NAN, C., ZHANG, H. and ZHAO, G. Allelopathic interactions between the macroalga Ulva pertusa and eight microalgal species. Journal of Sea Research, 2004, 52(4), 259-268. http://dx.doi.org/10.1016/j. seares.2004.04.001.

ONCEL, S.S., IMAMOGLU, E., GUNERKEN, E. and SUKAN, F.V. Comparison of different cultivation modes and light intensities using mono-cultures and co-cultures of Haematococcus pluvialis and Chlorella zofingiensis. Journal of Chemical Technology and Biotechnology (Oxford, Oxfordshire), 2011, 86(3), 414-420. http://dx.doi.org/10.1002/jctb.2532.

PERALES-VELA, H.V., GONZÁLEZ-MORENO, S., MONTES-HORCASITAS, C. and CAÑIZARES-VILLANUEVA, R.O. Growth, photosynthetic and respiratory responses to sub-lethal copper concentrations in Scenedesmus incrassatulus (Chlorophyceae). Chemosphere, 2007, 11(11), 2274-2281. http://dx.doi.org/10.1016/j. chemosphere.2006.11.036. PMid:17267014.

PINTO, E., SIGAUD-KUTNER, T.C., LEITAO, M.A., OKAMOTO, O.K., MORSE, D. and COLEPICOLO, P. Heavy metal-induced oxidative stress in algae. Journal of Phycology, 2003, 39(6), 1008-1018. http://dx.doi.org/10.1111/j.00223646.2003.02-193.x.

PISTOCCHI, R., GUERRINI, F., BALBONI, V. and BONI, L. Copper toxicity and carbohydrate production in the microalgae Cylindrotheca fusiformis and Gymnodinium sp. Eur. Journal of Phycology, 1997, 32(2), 125-132. http://dx.doi.org/10.1080/096702 69710001737049.

PRATT, R. and FONG, J. Studies on Chlorella vulgaris II. Further evidence that Chlorella cells form a growth-inhibiting substance. American Journal of Botany, 1940, 27(6), 431-436. http://dx.doi. org/10.1002/j.1537-2197.1940.tb14704.x.

PRATT, R., DANIELS, T.C., EILER, J.J., GUNNISON, J.B., KUMLER, W.D., ONETO, J.F., STRAIT, L.A., SPOEHR, H.A., HARDIN, G.J., MILNER, H.W., SMITH, J.H.C. and STRAIN, H.H. Chlorellin, an antibacterial substance from Chlorella. Science, 1944, 99(2574), 351-352. http://dx.doi. org/10.1126/science.99.2574.351. PMid:17750208.

RAJAPITAMAHUNI, S., BACHANI, P., SARDAR, R.K. and MISHRA, S. Co-cultivation of siderophoreproducing bacteria Idiomarina loibiensis RS14 with Chlorella variabilis ATCC 12198, evaluation of micro-algal growth, lipid, and protein content under iron starvation. Journal of Applied Phycology, 2018, 31(1), 1-11.

RIPPKA, R., DERUELLES, J. and WATERBURY, J.B. Generic assignments, strain histories and properties of pure cultures of cyanobacteria. Microbiology, 1979, 
111(1), 1-61. http://dx.doi.org/10.1099/00221287111-1-1.

SABATINI, S.E., JUÁREZ, A.B., EPPIS, M.R., BIANCHI, L., LUQUET, C.M. and RÍOS DE MOLINA, M.C. Oxidative stress and antioxidant defenses in two green microalgae exposed to copper. Ecotoxicology and Environmental Safety, 2009, 72(4), 1200-1206. http://dx.doi.org/10.1016/j. ecoenv.2009.01.003. PMid:19223073.

SANDERS, J.G. and CIBIK, S.J. Response of Chesapeake Bay phytoplankton communities to low levels of toxic substances. Marine Pollution Bulletin, 1988, 19(9), 439-444. http://dx.doi.org/10.1016/0025326X(88)90399-2.

SHRIVASTAVA, A.K. A review on copper pollution and its removal from water bodies by pollution control technologies. Indian Journal of Environmental Protection, 2009, 29(6), 552-560.

SILVA, J.C., ECHEVESTE, P. and LOMBARDI, A.T. Higher biomolecules yield in phytoplankton under copper exposure. Ecotoxicology and Environmental Safety, 2018, 161, 57-63. http://dx.doi.org/10.1016/j. ecoenv.2018.05.059. PMid:29859408.

SPOEHR, H.A. and MILNER, H.W. The chemical composition of Chlorella; effect of environmental conditions. Plant Physiology, 1949, 24(1), 120149. http://dx.doi.org/10.1104/pp.24.1.120. PMid:16654197.

TRIPATHI, B.N., MEHTA, S.K., AMAR, A. and GAUR, J.P. Oxidative stress in Scenedesmus sp. During short-and long-term exposure to $\mathrm{Cu}^{2+}$ and $\mathrm{Zn}^{2+}$. Chemosphere, 2006, 62(4), 538-544. http:// dx.doi.org/10.1016/j.chemosphere.2005.06.031. PMid:16084572.
WILDE, K.L., STAUBER, J.L., MARKICH, S.J., FRANKLIN, N.M. and BROWN, P.L. The effect of $\mathrm{pH}$ on the uptake and toxicity of copper and zinc in a tropical freshwater alga (Chlorella sp.). Archives of Environmental Contamination and Toxicology, 2006, 51(2), 174-185. http://dx.doi.org/10.1007/s00244004-0256-0. PMid:16583260.

WINDOM, H.L., BYRD, J.T., SMITH, R.G. Jr. and HUAN, F. Inadequacy of NASQAN data for assessing metal trends in the nation's rivers. Environmental Science \& Technology, 1991, 25(6), 1137-1142. http://dx.doi.org/10.1021/es00018a019.

YAN, H. and PAN, G. Toxicity and bioaccumulation of copper in three green microalgal species. Chemosphere, 2002, 5(5), 471-476. http://dx.doi.org/10.1016/ S0045-6535(02)00285-0. PMid:12363319.

YEN, H.W., CHEN, P.W. and CHEN, L.J. The synergistic effects for the co-cultivation of oleaginous yeast-Rhodotorula glutinis and microalgae-Scenedesmus obliquus on the biomass and total lipids accumulation. Bioresource Technology, 2015, 184, 148-152. http://dx.doi.org/10.1016/j.biortech.2014.09.113. PMid:25311189.

ZHAO, P., YU, X., LI, J., TANG, X. and HUANG, Z. Enhancing lipid productivity by co-cultivation of Chlorella sp. U4341 and Monoraphidium sp. FXY-10. Journal of Bioscience and Bioengineering, 2014, 118(1), 72-77. http://dx.doi.org/10.1016/j. jbiosc.2013.12.014. PMid:24491914.

Received: 15 January 2020 Accepted: 25 May 2021

Associate Editors: Kemal Ali Ger, André Andrian Padial. 